\title{
PREDICTORS OF RECIDIVISM FOR JUVENILE DELINQUENTS AF- TER THE TREATMENT IN THE DISCIPLINARY CENTRE
}

\author{
Ranko Kovačević ${ }^{1, a}$ \\ Edin Muftića \\ Nijaz Karićc \\ Vedad Gurda ${ }^{\mathrm{c}}$
}

Original scientific paper

UDC:343.91-053.6

343.815

364-053.6

\begin{abstract}
The goal of this study was to establish the variables that influenced recidivism in juvenile delinquents after the implemented treatment at the Disciplinary Centre for Juveniles in Canton Sarajevo, Federation of Bosnia and Herzegovina. The research was conducted on the sample of 131 juvenile delinquents adjudicated with the educational measure of referral to the juvenile disciplinary centre. The statistical analysis was performed in the SPSS 17.0 program package. The results demonstrated that the significant predictors for the occurrence of recidivism are unplanned spare time, socializing with peers of an unacceptable behaviour, poor academic success and the risk of pre-expulsion from school. The results indicate that the treatment should primarily be focused on these variables in order to contribute to the reduction of recidivism.
\end{abstract}

Key words: recidivism, educational measure, juvenile delinquents

\section{INTRODUCTION}

All societies and time periods had young people whose behaviour deviated from the socially acceptable norms, that community condemned or sanctioned in one way or the other. The response to the violation of the social norms by juveniles often implied rigorous punishment and isolation from the community, but such responses were not focused on the rehabilitation and resocialisation of offenders but rather on their punishment. We define juvenile delinquents as juveniles who have committed various delinquent acts, due to which a criminal proceedings were initiation. Juvenile delinquency, defined as criminal behaviour by children and adolescents continues to be a pervasive problem in the world (Perkins-Dock, 2001). Delinquent behaviour in a youth is usually that which would be considered if commited by an adult (Yoshikawa, 1995). With the development of the criminal law, a number of changes in the course of action taken and the prosecution of the juveniles were introduced. Changes in the legal and constitutional structure of Bosnia and Herzegovina led to the need to harmonise criminal legislation with the new political system as well as international standards. Complying with international standards was primarily directed on providing the additional protection of fundamental human rights and freedom, particularly juvenile delinquents (Žunić-Pavlović, Kovačević \& Bijedić, 2009). In modern criminal legistation, new educational measures as primary sanctions for juveniles are introduced, and juvenile imprisonment is pronounced only in exceptional cases and under special conditions.

\footnotetext{
Correspodence to:

Ranko Kovačević, PhD, Faculty of Education and Rehabilitation, University of Tuzla, Bosnia and Herzegovina

Univerzitetska 175000 Tuzla

Tel: 0038761855024

E-mail: ranko.kovacevic@untz.ba
} 
The question is how to respond to delinquent behaviour and with what methods, i.e. sanctions, while simulataneously ensuring that they take responsibility for their behaviour, remains a dilemma since it is necessary to establish a balance between the retributional and rehabilitational elements each sanction has (Ricijaš, 2012). Educational measures are now the largest and the most frequently pronoused type of criminal sanction for juveniles whose main aim is education, rehabilitation and the proper development of the juvenile (Koller-Trbović \& Juričanin, 1990). In the choice of the education measures, a significant place is reserved for the educational measure of referral to the Disciplinary Centre due to its specificities in relation to its implementation but also juveniles who are adjudicated with this measure. The educational measure of the referral to the Disciplinary Centre for Juveniles is pronounced by the court in accordance with the Article 89 of the Criminal Code of the Federation of Bosnia and Herzegovina. The court pronounces the educational measure of the referral to the Disciplinary Centre for Juveniles when there is a need for an appropriate short-term measure that affects the personality and the behaviour of a juvenile offender of a criminal act. A juvenile who was pronounced a measure from the Act 1 of this Article, may be referred to the Disciplinary Centre:

a)for a certain number of hours during a holiday, but no longer than four consecutive days of the holiday; holiday in terms of this measure is every unworked day: Sunday, holiday definite laws, as well as religious holiday

b)for a certain number of hours during a day, but no longer than a month;

c)For a continuos stay over a number ofdays, but not longer than twenty days (Kazneni zakon Federacije Bosne i Hercegovine, 2003).

Koller-Trbović stated that this is primarily a strong intensity short-term disciplinary measure with a significant spectrum of content and activities that have to be applied during the time it is conducted. The purpose of the imposition of these measures is that in a relatively short period of time a powerful impact on children is made via various strategies, in strictly structured conditions through direct methods aiming at behaviour modifications, directed at the development of a personal responsibility and an intense impact on the prevention of committing criminal acts in the future (Koller-Trbović \& Juričanin, 1990). Hence, that should be an authoritative, firmly structured educational measure with clearly defined demads, structure of the day, rules and obligations of juveniles, but also of those who pronounce and implement the measure. Changes that can be expected in a short period of time are the so-called changes of the first level of adaptation and racionalisation in order to accept social norms and way of life that in not in conflict with the rules of the society. In a system of the existing educational measures for juvenile delinquents, the measure of referral of the juvenile to the Disciplinary Centre for Juveniles should have a positive response among both professional employees and juveniles in conflict with the law (Lulić-Čavar, 1995). The efficiency of a method of treatment may be assessed by measuring the number of juveniles who again come into conflict with the law (recidivism) or other differet indicators of progress in social functioning (Mikšaj-Todorović \& Buđanovac, 1995). Recidivism is most frequently defined as any arrest or offending within specified follow-up period after release from a detention or rehabilitation facility (Wierson \& Forehand, 1995). Juvenile offenders are an important target for interventions aimed at the prevention of ongoing criminal behavior. Juvenile delinquency and recidivism are thought to be caused by a complicated interaction of risk factors (Loeber, Farrington, 2001). Recidivism can best be prevented if treatment targets the specifc risk factors that are present in serious juvenile offenders. For that reason, better understanding of these specific risk factors is needed to increase treatment eff ect with the aim to prevent persistence of criminal behavior and to reduce severity of recidivism (Schumacher, 2000). The main use of recidivism data is in evaluating the effectiveness of sentences or programs in reducing reoffending. In addition, there is a great deal of research on risk assessment to predict recidivism, which might assist criminal justice decision-makers in sentencing or release decisions (Farrington \& Davies, 2007). Cottle et all. (2001) published a meta-analysis of predictors of recidivism (rearrest) in juveniles, based on 23 studies. The best predictors were (in order) young age at first commitment, young age at first contact with the law, non-severe pathology, family problems, conduct problems, poor use of leisure time, delinquent peers, length of first incarceration, number of outof-home placements, number of prior commitments, type of crime, low achievement, substance abuse, low IQ, special education, history of abuse, male gender, single parent, minority race, and low socio-economic status (Farrington \& Davies, 2007 ). In this paper, the juvenile recidivism applies to those juveniles who are registered as re-offenders. This criterion of recidivism is more comprehensive because it involves all minors regardless of the type of criminal offense. 
Realistic insight into the occurrence and movement of criminal restitution in juvenile offenders will receive a refund if we look at in relation to the total applicants, not only to convicted minors, and therefore if we define the notion of return extensively, returnees and not merely those who are previously convicted, but also those who have just signed (Singer, 1996). Official data were used because they provide an objective and clear measure or recidivism (Heilbrun, 2000). Taking into account the above mentioned, the aim of this work is to establish the incidence of recidivism and the variables that contribute most to the occurrence of recidivism. The realisation of such goal presupposed determination of predictors of recidivism on a population of juvenile delinquents. It is expected that the isolated predictors of recidivism be a starting point for creating preventive programs through targeted interventions to reduce recidivism proportion of juvenile delinquents.

\section{METHODOLOGY}

\section{The sample}

The sample included 131 juvenile delinquents, aged between 14 and 18, of both genders, from the Canton of Sarajevo, who were, by the decision of the Court due to committing a delinquent act, referred to the Disciplinary Centre for Juveniles in Sarajevo, in the period between June 1, 2007, and June 30, 2013, and toward who the planned treatment program at the Disciplinar Centre was implemented in its entirety. Table 1 shows the distribution of participants in relation to gender.Table 1 demonstrated that in the total sample of 131 subjects, 121 subjects or $92.3 \%$ were male and 10 subjects or $7.7 \%$ were female. It is evident is the domination of male subjects.

Table 1. Distribution participants in relation to gender of juveniles

\begin{tabular}{ccccccc}
\hline & \multicolumn{9}{c}{ Gender } \\
\hline & Male & & \multicolumn{2}{c}{ Female } & \multicolumn{2}{c}{ Total } \\
$\mathbf{N}$ & $\mathbf{\%}$ & $\mathbf{N}$ & $\mathbf{\%}$ & $\mathbf{N}$ & $\mathbf{\%}$ \\
\hline 121 & 92,3 & 10 & 7,7 & 131 & 100,00 \\
\hline
\end{tabular}

\section{Measuring instrument}

Information of test subjects were collected using evaluation sheet containing data from the official records of the Ministry of Internal Affairs, Canton Sarajevo, in terms of monitoring juvenile recidivism, as well as the evaluation sheet on the assessment of the treatment program effects based on the analysis of the official records and documentation of expert employees of the Disciplinary Centre. Variable found in the instrument (the evaluation sheet) are categorised into four areas, namely: functioning in school, the family functioning, leasure time and peer relations. For the purposes of this study, variables used included the assessment of 21 independent variables. Variables were ranked by categories: 1 . Never, 2. Rarely, 3. Sometimes, 4. Often. The answer to each of the questions was presented in a form of the most favourable to the least favourable response for the test subject. Dependent variable is a variable related to recidivism and defined in categories: 1 . No, 2. Yes. To determine the occurrence of recidivism of juvenile delinquents data are obtained on the basis of the official records of the Ministry of Internal Affairs of the Canton Sarajevo during 3 months after completing treatment.

I group of variables is related to variables that describe the functioning in the school and includes six variables as follows:

1. Risk of the pre-expulsion from the school (RPES); 2. Poor academic success (PAS);

3. Violation of the rules of conduct in the classroom (VRCC);

4. Unexcused absences from school (UAS);

5. Lack of motivation for learning (LML);

6. Lack of studying habits (LSH);

II group of variables is related to variables describing family functioning and includes five variables, namely:

1. Problems of communication in the family (PCF);

2. Parents do not control stay outside of the family (PNCSOF);

3. Parents do not give tasks (obligations) to a juvenile (PNGT); 
4. Parent's permissiveness to juvenile's requests (PPJR);

5. Parents do not provide support in upbringing and education (PNPSUE);

III group of variables related to spare time activities and peer relationships, and includes three variables, namely:

1. Socialising with peers with unacceptable behaviour (SPUB);

2. Unplanned spare time (unstructured) (UST);

3. Going out on risky places (GORP);

IV group of variables related to the personality and behavior of juveniles and includes seven variables:

1. Interests inappropriate to their age (IITA);

2. Verbal aggression (VA);

3. Violent conflict resolution (VCR);

4. Failure to adopt work habits (FAWH);

5. Failure to adopt hygienic habits (FAHH);

6 . The lack of feeling of regret for inappropriate behavior (LFRIB);

7. Denying responsibility for bad actions (DRBA)

Data on juvenile recidivism were based on analysis of the official records and documents of the Ministry of Internal Affairs, the Canton of Sarajevo.

\section{Method of data collection}

The study was conducted in the Sarajevo Canton, the Cantonal Public Institution Disciplinary Centre for Juveniles and Ministry of Internal Affairs, Sarajevo Canton, in the period from March to May 2013. The study was conducted so that the data was collected on the basis of data from the personal files of wards, and through the evaluation of educators who have implemented the educational measure.

\section{Statistical Analysis}

The obtained data were processed on the latent level. The analysis of the predictive value of the variables that lead to the occurrence of recidivism was determined using the logistic regression analysis. The goal of the logistic regression analysis is to determine the correlation between a set of independent variables and one dependent variable. In logistic regression analysis, the independent variables are called predictors and the dependent variable criteria given that is defined as dichotomous.

\section{RESULTS}

Determining the prevalence and predictors of recidivism

Criminal recidivists are, a problematic part of any delinquent population. Data on the incidence of recidivism are shown in Table 2. Data are presented through absolute and relative frequencies.

Table 2. Frequency in relation to the incidence of recidivism

\begin{tabular}{|c|c|c|c|c|c|}
\hline \multirow{3}{*}{ VARIABLE } & \multicolumn{2}{|c|}{ NO } & \multicolumn{2}{|c|}{ YES } & \multirow{3}{*}{$\begin{array}{c}\text { TOTAL } \\
\%\end{array}$} \\
\hline & & & \multicolumn{2}{|c|}{$\%$} & \\
\hline & $\mathbf{N}$ & $\%$ & $\mathbf{N}$ & $\%$ & \\
\hline \multirow{2}{*}{ RECIDIVISM } & \multirow{2}{*}{111} & \multirow{2}{*}{84,8} & \multirow{2}{*}{20} & \multirow{2}{*}{15,2} & 131 \\
\hline & & & & & 100,00 \\
\hline
\end{tabular}

It is apparent from From the Table 2 that, out of 131 juveniles who were in treatment at the Disciplinary Centre, there is recidivism in a total of 20 juveniles. Given that the results shown that recidivism occurred in a number of juvenile delinquent who have had treatment in the Disciplinary Centre for Juveniles, we have attempted o determine the segment of the treatment i.e. variable that define it, that were in the focus of treatment and possibly responsible for recidivism. To determine the relation between the variables of treatment with the criteria variable was originally used Spearman's rank correlation coefficient. Table 3 shows the Spearman's rank correlation coefficient between variables of treatment with variable of recidivism. 
Table 3. Correlation (Spearman's) of variables treatmens with recidivism

\begin{tabular}{|c|c|c|}
\hline VARIABLES & Coefficient Correlation & $\mathbf{P}$ \\
\hline RPES & 0,390 & 0,000 \\
\hline PAS & 0,348 & 0,000 \\
\hline VRCC & 0,366 & 0,000 \\
\hline UAS & 0,349 & 0,000 \\
\hline LML & 0,376 & 0,000 \\
\hline LSH & 0,230 & 0,000 \\
\hline PCF & 0,360 & 0,000 \\
\hline PNCSOF & 0,335 & 0,000 \\
\hline PNGT & 0,246 & 0,005 \\
\hline PPJR & 0,335 & 0,000 \\
\hline PNPSUE & 0,229 & 0,008 \\
\hline SPUB & 0,618 & 0,002 \\
\hline UST & 0,439 & 0,006 \\
\hline GORP & 0,463 & 0,002 \\
\hline IITA & 0,333 & 0,000 \\
\hline VA & 0,335 & 0,000 \\
\hline VCR & 0,329 & 0,002 \\
\hline FAWH & 0,296 & 0,001 \\
\hline FAHH & 0,263 & 0,002 \\
\hline LFRIB & 0,370 & 0,000 \\
\hline DRBA & 0,394 & 0,000 \\
\hline
\end{tabular}

The table shows that the level of statistical significance of $\mathrm{p}<=.005$ all variables associated with recidivism. A larger number of variables have lower correlation coefficients as a variable that refers to socialize with peers unacceptable behavior showed significantly higher correlation coefficient. The predictor variables consisted of 21 variables that describe areas which were the focus of treatment, which describes how rela- tionships and functioning of juveniles in school, family, spare time and peer relations, as well as variables related to the personality and the behaviour of the juvenile. Given that the criterion variable is defined as dichotomous, the method used is logistic regression analysis, which established that the variables were significant predictors of recidivism. Table 4 . presents the basic parameters of the logistic regression analysis.

Table 4. Basic parameters of the logistic regression analysis

\begin{tabular}{lcccr}
\hline Chi-square & $\begin{array}{c}\text { Cox \& Snell R } \\
\text { Square }\end{array}$ & Nagelkerke R Square & $\begin{array}{c}\text { Percentage } \\
\text { Correct }\end{array}$ & p \\
\hline 55,794 & 0,347 & 0,604 & 84,7 & 0,000 \\
\hline
\end{tabular}


Logistic regression analysis was performed to determine which variables affect recidivism. The entire model contains 21 independent variable and statistically significant c2 $(21, \mathrm{~N}=131)=55.794$, $\mathrm{p}<.000$, indicating that the model is different subjects with and without recidivism. The model as a whole explained between 34.7\% (Cox \& Snell R Square) and $60.4 \%$ (Nagelkerke R Square) of the variance and correctly classified $84.7 \%$ of cases. The variables critical for the recidivism of juveniles, after the implemented treatment, are shown in Table 5.

Table 5. Results of Logistics regression anaysis for the criteria of recidivism

VARIABLES

B

SE
Standardized

(B) Coeficient

\begin{tabular}{|c|c|c|c|c|c|}
\hline RPES & 3,457 & 1,724 & 4,020 & 7,715 & 0,045 \\
\hline PAS & 5,694 & 2,181 & 6,816 & 6,213 & 0,006 \\
\hline VRCC & $-0,456$ & 1,334 & 0,117 & 1,578 & 0,732 \\
\hline UAS & 1,416 & 2,190 & 2,064 & 0,012 & 0,074 \\
\hline LML & 2,907 & 1,587 & 3,354 & 0,055 & 0,067 \\
\hline LSH & 0,425 & 1,540 & 0,076 & 1,529 & 0,783 \\
\hline PCF & $-1,147$ & 1,056 & 1,180 & 0,318 & 0,277 \\
\hline PNCSOF & 0,698 & 0,984 & 0,503 & 0,498 & 0,478 \\
\hline PNGT & $-0,199$ & 0,924 & 0,046 & 1,220 & 0,830 \\
\hline PPJR & 1,040 & 0,900 & 1,336 & 0,353 & 0,248 \\
\hline PNPSUE & $-0,619$ & 0,575 & 1,157 & 1,857 & 0,282 \\
\hline SPUB & $-4,221$ & 1,646 & 6,577 & 68,134 & 0,010 \\
\hline UST & 3,048 & 1,538 & 3,929 & 21,081 & 0,007 \\
\hline GORP & 1,231 & 1,853 & 0,441 & 0,292 & 0,506 \\
\hline IITA & 1,512 & 1,663 & 0,826 & 4,534 & 0,363 \\
\hline VA & 1,285 & 1,610 & 0,637 & 0,277 & 0,425 \\
\hline VCR & 0,543 & 1,153 & 0,222 & 0,581 & 0,638 \\
\hline FAWH & $-1,069$ & 0,858 & 1,551 & 2,911 & 0,213 \\
\hline FAHH & 0,172 & 0,529 & 0,106 & 0,842 & 0,745 \\
\hline LFRIB & $-0,259$ & 0,786 & 0,108 & 1,295 & 0,742 \\
\hline DRBA & $-0,756$ & 0,956 & 0,625 & 0,469 & 0,429 \\
\hline
\end{tabular}

Legend: 1. Risk of the pre-expulsion from the school (RPES); 2. Poor academic success (PAS); 3. Violation of the rules of conduct in the classroom (VRCC); 4. Unexcused absences from school (UAS); 5. Lack of motivation for learning (LML); 6. Lack of studying habits (LSH); 7. Problems of communication in the family (PCF); 8. Parents do not control stay out side of the family (PNCSOF); 9. Parents do not give tasks (obligations) to a juvenile (PNGT); 10. Parent's permissiveness to juvenile's requests (PPJR); 11. Parents do not provide support in upbringing and education (PNPSUE); 12. Socialising with peers with unacceptable behaviour (SPUB); 13. Unplanned spare time (unstructured) (UST); 14. Going out on risky places (GORP); 15. Interests inappropriate to their age (IITA); 16. Verbal aggression (VA); 17. Violent conflict resolution (VCR); 18. Failure to adopt work habits (FAWH); 19. Failure to adopt hygienic habits (FAHH); 20. The lack of feeling of regret for inappropriate behaviour (LFRIB); 21. Denying responsibility for bad actions (DRBA) 
It is evident from the table 4 that out of 21 observed variable, there were only five variables that indicate statistical relevance i.e. for which we may say represent predictors for the occurrence of recidivism in juveniles. Those variables refer to the unplanned use of spare time $(\beta=21,081, p=<0,007)$, socialising with peers with an unacceptable behavior $(\beta=$ $68,134, \mathrm{p}=<0,010)$, poor academic success $(\beta=$ $6,213, \mathrm{p}=<0,006)$ and the risk of pre-expulsion from school $(\beta=7,715, p=<0,045)$. Given that the size of the beta coefficient $(68,134)$ and the correlation coefficient $(0,618)$ the variable 'socialising with peers with an unacceptable behavior' is the best predictor of recidivism. The results obtained in the Table 4 indicate that these variables influenced to the greatest extent recidivism in juveniles who have undergone the treatment. If we observe the structure of these variables, it is evident that they refer to the spare time and spending time with persons of an unsocial behaviour, and they logically progress to the variable of the risk of pre-expulsion from school, that was to the largest extent related to being absent from classes (the area of school), and sa such provide juveniles with a possibility of having more spare time and going out to risky places. The remaning 17 observed variables indicate no statistical relevance, and as such they shall not be interpreted.

\section{DISCUSSION}

Results obstained in this study indicate that four variables are most closely associated with recidivism. In the regard to the pronounced correlation coefficient and the size of the beta coefficient, variable of socialising with peers with unacceptable behaviour' is the best predictor of recidivism. Criminological research has confirmed that socializing with people antisocial behavior one of the highest forms of behavior disorders in juvenile delinquents (Boiuillet \& Uzelac, 2007). Association with antisocial peers has been identified as an important risk factor for delinquency (Bender, 2010). According to Hansen, this type of behavior disorders in one of the most consistent and most reliable predictors of juvenile delinquency (Hansen, 1997). Delinquent peer associations are also important in predicting general delinquent recidivism (Hoge \& Andrews, 2002). Deviant peer affiliation is a stronger predictor of delinquent behavior than variables such as family, school, and community characteristics (Elliott \& Menard, 1996). According to McCord and colleagues fac- tors such as peer delinquent behavior, peer approval of delinquent behavior, attachment or allegiance to peers, time spent with peers, and peer pressure for deviance have all been associated with adolescent antisocial behaviour (McCord \& Widom, 2001 ).

Associal persons attempt to attract new people in their closer environment by any means, and they usually find them among juveniles who are unstable or with poor upbringing. Groups that do bad things are often of a temporary character and loose structure. Bouillet and Uzelac (2007) cite results of the research conducted in Croatia and point out that recidivism is associated with a number of variables, emphasising among other socialising with people of an anti-social behaviour. The degree of integration of juveniles in the group of a deviant, and even delinquent behavior, is usually higher as a juvenile is less tied to the family, less integrated into the educational process or unemployed. Unplanned spare time is a variable that singled out as a predictor of recidivism. Many authors came to the conclusion in their research that spare time may lead to juvenile delinquency if not planned, programmed, structured. Therefore, this variable, along with socialising with anti-social individuals is in a significant correlation with interruption of the schooling due to the influence of such persons in juvenile's attitude toward school and studying (Singer et all, 1995). Our results concur with findings that poor academic achievement correlates with recidivism. In itself, poor academic achievement is a striking predictor for delinquency recidivism (Cottle, Lee \& Heilbrun, 2001). Research suggests that poor academic performance, truancy and bad conduct in the classroom are all potential precursors for the future criminal behaviour (MacRae et all, 2011). Unplanned spare time is a variable that singled out as a predictor of recidivism. Many authors came to the conclusion in their research that spare time may lead to juvenile delinquency if not planned, programmed, structured. Therefore, this variable, along with socialising with anti-social individuals is in a significant correlation with interruption of the schooling due to the influence of such persons in juvenile's attitude toward school and studying (Singer et all, 1995).

This study has limitations that should be taken into account, related to the fact that there was insufficient research on the recidivism of juvenile perpetrators in the area of the Bosnian and Herzegovinian institutions due to the lack of institutions for the implementation of measures. 


\section{CONCLUSION}

Given the set aim of the research, to establish the recidivism predictors, the implemented research and the interpretation of the results, the following conclusions can be made: the unplanned use of the spare time, socialising with peers of an unacceptable behaviour, poor academic success and the risk of pre-explusion represent the most frequent predictors of recidivism. The unplanned use of spare time evidently further generates the risk of socialising with peers of an unacceptable behaviour, going out to risky places and the risk of pre-explusion from school as the research results indicate. Results of this research indicate that these variables need to be devoted special attention. Persons in criminal recidivism, generally speaking, are a problematic part of any delinquent population. Usually those are persons that are "stubborn" in their unlawful conduct and that have spent most of their life in conflict with societal norms. It is important to note the fact that juvenile crime returnees manifest severe forms of behaviour disorders, and that they are not rooted in any educational environment, family or school. The isolated predictors of recidivism indicate the need to empower the treatment program and activities in the field of structuring the spare time of juveniles, to empower the work in the field of positive selection of the peer group and the socialisation with peers of an unacceptable behaviour, in general, as well as to strengthen the control and surveillance of the juvenile's going out to risky places as well as to establish a better cooperation of the Disciplinary Centre with other educational institutions with an aim of reducing the risk of being expulsion from the school.

\section{REFERENCES}

Bender, K. (2010). Why do some maltreated youth become juvenile offenders? A call for further investigation and adaptation of youth services. Children and Youth Services Review, 32, 466473.

Boiuillet, D., and Uzelac, S. (2007). Osnove socijalne pedagogije. Zagreb: Školska knjiga.

Cottle, C. C., Lee, R. J., and Heilbrun, K. (2001). The prediction of criminal recidivism in juveniles: A meta-analysis. Criminal Justice and Behavior, 28, 367-394.

Elliott, D.S, and Menard, S. (1996). Delinquent friends and delinquent behavior: Temporal and developmental patterns. In: Hawkins, J.D. editor. Delinquency and crime: Current theories. Cambridge criminology series. Cambridge University Press; New York, 28- 7.

Farrington, D. P., and Davies, D. T. (2007). Repeated Contacts with the Criminal Justice System and Offender Outcomes. Ot- tawa: Canadian Centre for Justice Statistics. Statistics Canada. Hansen, W.B. (1997). Prevention programs: Factors that individually focused program must address. Resourch papers. Rock-wille, 53-55.

Heilbrun, K. et all. (2000). Risk factors for juvenile criminal recidivism. The postrelease Community adjustment of juvenile off enders. Criminal justice and behavior. 27 (3), 275-291.

Hoge, R. D., and Andrews, D. A. (2002). Youth Level of Service/Case Management Inventory: User's Manual. North Towanda, NY: Multi-Health Systems.

Kazneni zakon Federacije Bosne i Hercegovine (Službene novine Federacije BiH broj: 36/03, 37/03, 21/04, 69/04, 18/05, 42/10). Sarajevo, 2003.

Koller-Trbović, N., and Juričanin, T (1990). Evaluacija nekih obilježja tretmana u okviru Disciplinskog centra za maloljetnike. Zagreb: Defektologija.

Loeber, R., and Farrington, D.P. (2001). The significance of child delinquency. Child delinquents: development,intervention and service needs. Thousand Oaks, CA: Sage, 2001; 1-21.

Lulić-Čavar, G. (1995). Neki aspekti evaluacije učinkovitosti tijeka izvršenja odgojne mjere upućivanje u disciplinski centar za maloljetnike. Kriminologija i socijalna integracija, 3(1): 5370.

MacRae, L.D., Lorne, D.B., Joanne, J.P., and Joseph, P.H. (2011). Relating risk and protective factors to youth reoffending: a two year follow up. International Journal of Child, Youth and Family Studies, 2 (1), 172196.

McCord, J., Widom, C.S., and Crowell, N.A. (2001). Juvenile crime, juvenile justice, panel of juvenile crime: prevention, treatment and control. Washington, DC: National Academy Press.

Mikšaj-Todorović Lj, and Buđanovac, A. (1995). Penološka rehabilitacija I. Interna skripta. Zagreb: Defektološki fakultet Sveučilišta u Zagrebu.

Perkins-Dock, R. E. (2001). Family interventions with incarcerated youth: A review of the literature. International Journal of Offender Therapy and Comparative Criminology, 45(5): 606625.

Ricijaš, N. (2012). Procjena planiranje i izvještavanje u izvršenju maloljetničkih alternativnih sankcija. Zagreb: Ministarstvo socijalne politike i mladih Republike Hrvatske.

Schumacher, M., and Kurz, G.A. (2000). The 8\% solution: preventing serious, repeat juvenile crime. Sage Publications.

Singer, M., et all. (1995). Sociodemografske i fenomenološke karakteristike kriminaliteta maloljetnika na području Županije Varaždinske. Fakultet za defektologiju Sveučilišta u Zagrebu. Visoka policijska škola MUP-a RH.

Singer, M. (1996). Krimonologija drugo izdanje. Zagreb: Globus.

Yoshikawa, H. (1995). Long-term effects of early childhood programs on social outcomes and delinquency. The Future of Children, 5, 51-75.

Wierson, M., and Forehand, R. (1995). Predicting recidivism in juvenile delinquents: The role of mental health diagnoses and the qualification of conclusions by race. Behaviour Research and Therapy 33, 63-67.

Žunić-Pavlović, V., Kovačević, R., and Bijedić, M. (2009). Uporedna analiza maloletničke delinkvencije i krivičnopravne reakcije u FBiH i RS u periodu od 2001-2007 godine. Edicija: Radovi i Monografije. Beograd: Istraživanja u specijalnoj pedagogiji, 49-64. 